\title{
СТАНОВЛЕННЯ НОРМАТИВНО-ПРАВОВОЇ БАЗИ Й ОРГАНІЗАЦЙНИХ ОСНОВ ДЕРЖАВНОЇ ДОПОМОГИ ДІТЯМ В УСРР 1920-х pp.
}

Анотація: У статті досліджується початок формування нормативно-правової бази надання державної допомоги дітмм у 1920-х рр. Встановлено, що з приходом більшовиків до влади було реалізовано їх ідею про передачу всієї раніше сформованої системи соиіального забезпечення дітей у відання радянської держави. Відбувалася докорінна трансформація старої системи соціального захисту дитинства та виникнення ї нових напрямів. Радянська влада оголосила охорону прав неповнолітніх пріоритетом своєї діяльності. 3 реалізацією такої політики радянської влади відразу загострилася низка соціальних проблем, серед яких першочергового вирішення вимагала саме проблема масової дитячої безпритульності та бездоглядності. З'ясовано розуміння на той час поняття «безпритульність» і застосування його у тогочасних нормативно-правових актах.

Соціальний захист дитинства виражався у формуванні нормативної бази, різноманітних державних і громадських організацій з охорони прав неповнолітніх, у створенні різного роду дитячих установ, у наданні матеріальної та правової допомоги дітям та їх родинам, у доступності загальної та професійної освіти, у пращевлаштуванні підлітків, охороні їх праці.

Організаційно оформилася діяльність кількох структур, які займалися соціальним захистом дітей: Наркомат освіти, Наркомат внутрішніх справ, Наркомат шляхів сполучення; міжвідомча Комісія з поліпшення життя дітей при ВЦВК координувала зусилля всіх відомств.

Ключові слова: Українська СРР, РСФРР, декрет, постанова, комісії, громадські організації, допомога дітям, безпритульність

У сучасних умовах розвитку українського суспільства та побудови незалежної правової держави закономірно посилюється інтерес до проблем дитинства та материнства, підростаючого покоління, здійснюються заходи з покращення демографічної ситуації в країні, удосконалюються процедури усиновлення дітей, створюються дитячі будинки сімейного типу, підвищується матеріальне забезпечення дітей-інвалідів тощо. У зв'язку 3 цим зростає значення історичних знань, актуалізується досвід попередніх поколінь, створюючи об'єктивний образ минулого, а історія забезпечує живий зв'язок часу, сприяє використанню практики в якості відправного моменту сучасних політичних і соціальних дій.

Сучасний період історії України характеризується відмовою від ще донедавна панівної ідеології, ламанням сформованих упродовж тривалого часу стереотипів, відкиданням колишніх цінностей та істин. Усе це разом змушує сучасних дослідників по-новому

\footnotetext{
• Білоконь Анастасія Сергіївна - аспірантка кафедри історії України Уманського державного педагогічного університету імені Павла Тичини (Умань, Черкаська область, Україна); ORCID: https://orcid.org/0000-0003-2872-5751; e-mail: bilokon_95@ukr.net
} 
дивитися на пройдений країною шлях, переглянути підходи до різних явищ нашої недавньої історії. Зокрема, це стосується і специфічних рис діяльності держави у питаннях допомоги дітям, боротьби з безпритульністю та бездоглядністю неповнолітніх упродовж 1920-х рр. Часто в історіографії радянського періоду простежується тенденція від прикрашання реальних досягнень та ідеалізація соціальної політики держави у «дитячому» питанні до повного його забуття. У результаті, такі важливі проблеми, як заходи центральних державних органів зі створення інституцій допомоги дітям, боротьби 3 дитячою безпритульністю та бездоглядністю, складності утримання дітей у дитячих закладах, соціальна допомога закордонних благодійницьких організацій дітям вулиці не отримали достатнього висвітлення.

Дослідженням питань діяльності центральних державних органів 3 нормативноправового оформлення боротьби 3 дитячою безпритульністю, надання їм необхідної правової та матеріальної допомоги, соціального захисту в історичному ключі займалася незначна кількість вітчизняних і зарубіжних (переважно - російських) вчених. Цінним для аналізу у цьому аспекті є науковий доробок авторів радянської доби, які часто були сучасниками тих подій․ㅠ Їх праці мають потужну ідеологічну складову, однак уважне їх прочитання дає реальну картину повсякдення окреслених проблем. Серед сучасних українських дослідників, що займалися питаннями державної допомоги дітям у 19201930-ті рр., варто назвати праці Т. Букрєєва ${ }^{2}$, О. Міхєєвої ${ }^{3}$, Г. Лялюк ${ }^{4}$, О. Козлової두 О. Штань.

Враховуючи необхідність об'єктивного, всебічного та критичного аналізу державної політики надання допомоги неповнолітнім у перші десятиліття радянської влади, за мету нашої статті ставимо висвітлення історико-правових аспектів діяльності держави 3 організації допомоги неповнолітнім. Питання охорони материнства і дитинства актуальні в усі часи. Особливої гостроти вони набувають у періоди соціально-економічних криз і суспільно-політичних перетворень, які характерні й для сучасного періоду нашої історії.

До революції 1917 р. у Російській імперії, складовою частиною якої була й Україна, існувала досить розвинена система соціальної опіки дітей, яка грунтувалася в основному на громадській і приватній благодійності, що діяла під суворим контролем держави. Більшовики, взявши владу в свої руки, почали реалізовувати ідею про передачу всієї системи соціального забезпечення дітей у відання держави. Дослідження джерел 3 окресленої нами проблеми дає можливість з'ясувати, що з перших місяців радянської влади

\footnotetext{
${ }^{1}$ Куфаев В.И. Причины детской беспризорности. Вестник просвещения. 1924. № 9. С. 118-134; Куфаев В.И. Деятельность комиссий по делам несовершеннолетних в РСФСР за 1921 г. Народное просвещение. 1922. №105. С. 4-5; Лившии Е.С. Социальные корни беспризорности. Москва: «Работник просвещения», 1925; Люблинский П.И. Борьба с преступностью в детском и юношеском возрасте: социально-правовые очерки. Москва: Юрид. лит., 1923.

${ }^{2}$ Букрєєв Т. Дитячий будинок як «історична необхідність» в період формування радянської тоталітарної системи. Наукові записки Тернопільського національного педагогічного університету імені Володимира Гнатюка. Серія «Історія». 2017. С. 88-94.

${ }^{3}$ Міхеєва О.К. Сирітство, безпритульність та злочинність неповнолітніх у 1920-ті рр. в контексті соціальнодемографічних процесів. Історичні та політологічні дослідження. 2013. № 1. С. 120-128.

${ }^{4}$ Лялюк Г.М. Опікунсько-виховна діяльність інституційних установ на Лівобережній Україні (1918-1939рр.). Педагогіка формування творчої особистості у вищій ізагальноосвітній школах. 2020. №70. Т. 2. С. 33-38.

${ }^{5}$ Козлова О., Штань О. Досвід подолання дитячої безпритульності в СРСР та Європі у 1920-1930 рр. Педагогічні науки: теорія, історія, інноваційні технології. 2018. № 9 (83). С. 135-145.
} 
загострилася низка соціальних проблем, серед яких першочергового вирішення вимагала саме проблема масової дитячої безпритульності та бездоглядності. Визначення терміну безпритульності у досліджуваний період були дані у 1921 р. на конференції 3 питань соціально-правової охорони неповнолітніх, Головсоцвихом Наркомату освіти УСРР, а також дослідниками М. Гернетом, С. Познишевим, П. Люблинським, В. Куфаєвим ${ }^{6}$. Узагальнення всіх визначень дало можливість сформувати уявлення про розуміння безпритульності політикумом і суспільством 1920-х рр. Під цим терміном розуміли відсутність у дітей і підлітків постійного місця проживання, певних занять, сімейного або державного піклування та систематичного виховного впливу в результаті втрати батьків, втечі з сімї̈ чи з виховного закладу.

Варто підкреслити, що сама по собі проблема дитячої безпритульності для суспільства була не новою. Ї̈̈ нова хвиля піднялася на початку 1920-х рр. як наслідок тривалих війн, революцій, економічної кризи, репресій і соціальних потрясінь. Ця проблема вимагала негайного їі вирішення, загрожуючи вийти 3-під контролю й обернутися соціальною катастрофою. Злочинність, поширення хвороб, дитяча проституція, висока смертність серед неповнолітніх - це ті похідні безпритульності та бездоглядності неповнолітніх, які можна було локалізувати у часі. Для цього новій владі потрібно було задіяти всі свої механізми правові, політичні й економічні, організувати взаємодію центральних і місцевих органів влади, громадських організацій, педагогічних і медичних закладів, соціальних структур.

Зі встановленням радянської влади у країні відбувалася докорінна трансформація старої системи соціального захисту дитинства та виникнення іï нових напрямів. Радянська влада оголосила охорону прав неповнолітніх пріоритетом своєї діяльності. Для цього вже 12 грудня 1917 р. російським Раднаркомом було видано постанову про скасування ради дитячих притулків відомств установ імператрищі Марії, постійної комісії ради, господарський комітет, комітет для збору пожертв, комітет 3 пошуку засобів для влаштування хворих дітей на лікування до літніх санаторіїв ${ }^{7}$. Натомість декретом по Наркомату державного піклування «Про організацію колегії з охорони і забезпечення материнства та дитинства» від 31 грудня 1917 р. за підписом наркома О. Коллонтай новоствореному органу пропонувалося негайно організувати при головному управлінні міністерства «Відділ 3 охорони материнства та дитинства» та прийняти до нього всі матеріали та майно колишнього Всеросійського піклування з охорони материнства, а також, за наявності, грошові кошти. Колегія також мала негайно приступити до створення у приміщеннях колишнього жіночого інституту імператора Миколи II та жіночого Олександрівського училища в Москві «Палацу материнства» як центральної установи Всеросійської державної організації з охорони у радянській республіці материнства і дитинства ${ }^{8}$.

Та на цьому троща новою владою здобутків минулого не припинилася. Продовжуючи боротися 3 «царським минулим», відомство під керівництвом О. Коллонтай уже 12 січня

\footnotetext{
${ }^{6}$ Сажина Н.С. Деятельность государства и общественных организаций по ликвидации детской беспризорности в 1921-1928 гг. (на материалах Урала): Автореф. дис... канд. ист. наук: 07.00.02. Екатеринбург, 2003. С. 17.

${ }^{7}$ Собрание узаконений и распоряжений рабочего и крестьянского правительства за 1917. Отдел первый. 29 декабря. №11. Ст. 165.

${ }^{8}$ Собрание узаконений и распоряжений рабочего и крестьянского правительства. 1917-1918 гг. Управление делами Совнаркома СССР. Москва, 1942. С. 210.
} 
1918 р. видало новий декрет «Про скасування Всеросійського піклування 3 охорони материнства і дитинства». Установа, що була утворена у 1913 р. іменним указом царя Миколи II і діяла під управлінням імператриці Олександри Федорівни, тепер ліквідовувалася. Усі справи, звітність, майно та залишки коштів, що отримувалися піклуванням з різних джерел, тепер передавалися до колегії новоутвореного при Міністерстві піклування «Відділу з охорони материнства та дитинства» ${ }^{9}$.

Змін зазнала і система покарання юних правопорушників та злочинців. Скопіювавши окремі аспекти системи соціального захисту неповнолітніх зі зразків, що практикувалися в країнах Західної Європи та США, використовуючи передові розробки вітчизняних фахівців, радянська держава почала відмовлятися від застосування лише каральних заходів щодо неповнолітніх, створивши цілий комплекс заходів виховного та профілактичного характеру.

Соціальний захист дитинства виражався у формуванні нормативної бази, різноманітних державних і громадських організацій з охорони прав неповнолітніх, у створенні різного роду дитячих установ, у наданні матеріальної та правової допомоги дітям та їх родинам, у доступності загальної та професійної освіти, у працевлаштуванні підлітків, охороні їх праці. Нормативно-правова база соціальної політики стосовно безпритульних дітей формувалася упродовж усього досліджуваного періоду, здійснювалися постійні реорганізації управлінської структури державних органів. Зокрема, зазнав змін механізм ліквідації правопорушень серед безпритульних. 17 січня 1918 р. було прийнято декрет РНК РСФРР «Про комісії для неповнолітніх», які створювалися при Народному комісаріаті державного піклування і складалися 3 представників відомств: громадського піклування, народної освіти та юстиції в кількості не менше трьох осіб, один з яких повинен бути лікар ${ }^{10}$. Декретом скасовувалися суди та тюремні ув'язнення для неповнолітніх. Справи неповнолітніх правопорушників, яким не виповнилося 17 років, розглядалися лише Комісіями для неповнолітніх. Без сумнівів, цей декрет мав особливе значення, якщо говорити про безпритульних дітей, оскільки саме їм досить часто доводилося стикатися 3 кримінальним законодавством.

Ці комісії проіснували до 1935 р. й упродовж усього періоду їх повноваження неодноразово піддавалися законодавчому корегуванню. Декретом РНК РСФРР від 4 березня 1920 р. встановлювалося, що вік осіб, які підпадали під контроль Комісій для неповнолітніх було підвищено до 18 років. Пізніше за Кримінальним кодексом 1922 р. вік загальної осудності знижувався до 16 років. Однак тепер, якщо Комісії при розгляді справи по неповнолітньому старшому 14 років визнавав неможливість застосування заходів медико-педагогічного впливу, то справа передавалася до народного суду. Цим же декретом і підкреслювалося, що дітей у в'язницях потрібно розміщувати окремо від дорослих злочинців, щоб обмежити їх від негативного впливу останніх. У період свого створення Комісії для неповнолітніх перебували у віданні Народного комісаріату державного піклування, але згідно декрету від 4 березня 1920 р. вони перейшли у підпорядкування Наркомату освіти та його губернських і повітових органів ${ }^{11}$.

\footnotetext{
${ }^{9}$ Ibid. C. 253.

${ }^{10}$ Декрет СНК РСФСР «О комиссиях для несовершеннолетних». Собрание узаконений и распоряжений рабочего и крестьянского правительства РСФСР. 1918. 17 января. № 16. Ст. 227.

${ }^{11}$ Бендер Е.А. Правовые основы борьбы с детской беспризорностью в РСФСР в 1920-1930-е годы. Труды исторического факультета Санкт-Петербургского университета. 2013. С. 179.
} 
У лютому 1918 р. Наркоматом державного піклування було прийнято постанову«Про перехід у відання Народного комісаріату державного піклування всіх установ піклування про неповнолітніх i малолітніх дітей та про заснування Колегії піклування про неповнолітніх ${ }^{12}$. Тепер притулки, колонії й установи піклування всіх категорій переходили у підпорядкування Наркомату державного піклування, а їх утримання здійснювалося за рахунок коштів державного бюджету. Колегія піклування про неповнолітніх складалася 3 відділів: материнства та дитинства; неповнолітніх, що обвинувачувалися у суспільнонебезпечних діяннях; притулків загального характеру (для дітей дошкільного віку від 3 до 7 років і шкільного віку від 7 до 12 років і від 12 до 17 років). Усі інші притулки та установи для неповнолітніх, що не були прийняті Колегією у своє відання, на які б кошти вони не існували, ліквідовувалися, а їх майно та капітали передавалися державі.

Війни та революції, які часто ініціюються та розпалюються фанатично налаштованими політичними угрупуваннями, зорієнтованими на швидкий результат для реалізащії ї вузьких інтересів, з надією на докорінні зміни на краще, у кінцевому підсумку обертаються важкими людськими та матеріальними втратами, жертвами серед мирного населення, погіршенням суспільно-політичної та соціально-економічної ситуації, гуманітарною катастрофою. Унаслідок таких воєнних і революційних потрясінь виникає сирітство, дитяча безпритульність і бездоглядність, злочинність серед неповнолітніх. Серед перших нормативних актів радянської влади, покликаних надати посильну допомогу учасникам i жертвам війни, був декрет РНК РСФРР «Про пенсійне забезпечення солдатів Робітничо-

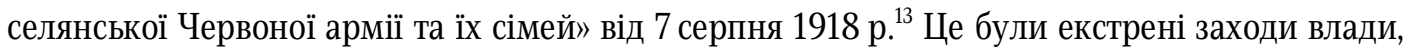
якими встановлювалося пенсійне забезпечення військовослужбовців Червоної армії та їх сімей. Осіб, які втратили працездатність під час військової служби, було поділено на 4 розряди та застосовано диференційований підхід при нарахуванні пенсій. Такий же принцип грошового забезпечення було застосовано і до сімей загиблих військових. Круглі сироти, що не досягли 17-річного віку, або діти-інваліди, забезпечувалися пенсією, призначуваними $з$ окладу глави сімії з розрахунку: на одну дитину - в розмірі половини цього окладу, на двох дітей - 3/4 від суми окладу, троє і більше дітей - у розмірі повного окладу загиблого глави сім'ї.

У лютому 1919 р. за підписами голови РНК РСФРР В.Леніна та Наркома освіти А. Луначарського було видано декрет «Про створення Ради захисту дітей» ${ }^{14}$. До ії складу входили по одному представнику від Наркоматів освіти, соціального забезпечення, охорони здоров'я, продовольства та праці. Цей особливий орган виконував більше функції швидкої допомоги у розвяязанні дитячих питань і не був розрахований на довготривалу дію. До обов'язків Ради входило: організація дитячих будинків і колоній, ї фінансування, забезпечення кадрами, питання евакуації й облаштування дітей, що прибували з голодних губерній. Проіснувала Рада захисту дітей до 1921 р., але результати ії роботи у вирішенні питань боротьби з безпритульністю були очевидними та неоціненними.

У структурі Наркомату освіти УСРР, губернських і повітових відділів освіти на початку

\footnotetext{
${ }^{12}$ Собрание узаконений и распоряжений рабочего и крастьянского правительства. 1917-1918 гг.... С. 327-328.

${ }^{13}$ Ibid. C. 778-779.

${ }^{14}$ Постановление Совета Народных Комиссаров РСФСР «Об учреждении Совета Защиты Детей». Собрание узаконений и распоряжений рабочего и крестьянского правительства РСФСР. 1919. 10 февраля. № 3. Ст. 32.
} 
1920-х рр. було створено відділи соціального виховання (Головсоцвих, губсоцвих, повітсоцвих), на які покладалися функщії соціально-правового захисту дитинства та боротьби з дитячою безпритульністю. У складі Головсоцвиху функціонували підвідділи: Загально-організаційний, Охорони дитинства, Науково-педагогічний, Дитячих установ, Соціально-правової охорони неповнолітніх і виховання дефективних - СПОН. Вони відали науково-теоретичними дослідженнями проблем дитячої безпритульності, опікою, патронатом, фінансуванням, забезпеченням і соціально-правовим захистом дітей, організацією мережі дитячих закладів ${ }^{15}$.

3 початку 1920-х рр. у країні розпочалося створення системи державних органів центрального та місцевого рівнів, головним завданням яких визначалася ліквідація безпритульності та надання невідкладної допомоги дітям. Важливу роль у соціальному захисті дітей відіграли декрети від 14 січня і 4 березня 1920 р. «Про скасування судів і тюремних ув'язнень для неповнолітніх» і створення циркуляром РНК РСФРР від 1 листопада 1921 р. Дитячої соціальної інспекції.

Постановою від 10 лютого 1921 р. при ВЦВК було створено Комісію з поліпшення життя дітей. Частіше застосовувалася інша назва - Дитяча комісія при ВЦВК. Відповідно до Положення про Дитячу комісію при ВЦВК, на посаді її голови повинен був перебувати за сумісництвом голова Всеросійської надзвичайної комісії, яку тоді очолював Ф. Дзержинський. Його заступником призначався також представник Всеросійської надзвичайної комісії. Окрім голови, до їі складу спочатку входили представники Наркоматів освіти, охорони здоров'я, продовольства, Всеросійської надзвичайної комісії, Робітничо-селянської інспекції, Всеросійської центральної ради професійних спілок. При Комісії діяв Секретаріат і ревізійна комісія. Секретаріат складався з управління справами та відділів: організаційно-інструкторського, пошуку засобів, суспільних прибутків. Місцевими органами Комісії були дитячі комісії при виконавчих комітетах республіканських, крайових, обласних, районних і міських рад. 3 вересня 1930 р. при Комісії було створено державне обєднання виробничих і торговельних підприємств, якому підпорядковувалося 17 підприємств ${ }^{16}$.

Дитяча комісія при ВЦВК була єдиним міжвідомчим надзвичайним органом, який зосереджував під своїм керівництвом усі питання забезпечення дітей і захисту їх інтересів. Ключовими завданнями Комісії були: організація допомоги з постачання продовольством, житлом і паливом установ, що займалися питаннями охорони життя та здоров'я дітей; контроль за виконанням постанов центральних і місцевих органів управління; підготовка і видання розпоряджень, що стосувалися охорони життя і здоров'я дітей ${ }^{17}$.

Вирішення усіх цих завдань Комісія повинна була здійснювати через органи центральних відомств. На місцях створювалися губернські та повітові Дитячі комісії, які спиралися на виконкоми та місцеві органи Наркомату освіти УСРР. Їх робота

\footnotetext{
${ }^{15}$ Паращевіна О.С. Роль системи народної освіти у подоланні дитячої безпритульності в $20-\mathrm{x}$ - першій половині 30-х рр. ХХ століття в Україні: Автореф. дис... канд. іст. наук: 07.00.01. Дніпропетровськ, 2005. С. 9. ${ }^{16}$ Декрет ВЦИК от 10 февраля 1921 г. «О Комиссии при Всероссийском Центральном Исполнительном комитете по улучшению жизни детей». URL: http://www.libussr.ru/doc_ussr/ussr_848.htm

${ }^{17}$ Сборник действующих узаконений и распоряжений партии и правительства, постановлений Деткомиссии ВЦИК и ведомственных распоряжений по ликвидации детской беспризорности и безнадзорности. Вып. 4. Москва, 1936. С. 97.
} 
контролювалася та координувалася спеціальними уповноваженими Дитячої комісії при ВЦВК. Спеціальні інструкції, циркуляри зобов'язували місцеві виконкоми, парткоми, продовольчі комітети та професійні спілки надавати всіляку допомогу в роботі 3 покращення життя дітей ${ }^{18}$. До квітня 1921 р. у складі Комісії при ВЦВК було створено 14 підкомісій 3 досить широкими повноваженнями. Їх діяльність організовувалася за наступними напрямами: фінансування, постачання, харчування дітей, будівнищтво та ремонт дитячих установ. Окрема підкомісія займалася збором статистичних даних про чисельність безпритульних дітей на місцях ${ }^{19}$.

Саме керівництво Дитячої комісії при ВЦВК намагалося надати стрункості системі управління справами дитинства та навести у цій сфері єдиний загальнодержавний порядок. До 1925 р. Дитяча комісії функціонувала на основі декрету ВЦВК від 10 лютого 1921 р. 2 лютого 1925 р. було затверджено Положення про Комісію поліпшення життя дітей при ВЦВК $^{20}$, яке основним завданням визначало надання, у першу чергу, допомоги безпритульним дітям. Проіснувала Дитяча комісія при ВЦВК до вересня 1938 р.

У період 1923-1924 рр. заходи боротьби з дитячою безпритульністю набувають білыш організованого та планового характеру. До цієї справи стали залучати громадськість шляхом створення спеціальних організацій. Так виникло товариство «Друзі дітей», фонд імені В. Леніна, які досить успішно діяли і в Україні. До 1924 р. організаційно оформилася діяльність кількох структур, які займалися соціальним захистом дітей: Наркомат освіти (зокрема, підвідділ соціально-правової охорони неповнолітніх); Наркомат внутрішніх справ (у віданні якого перебували установи для неповнолітніх злочинців); Наркомат шляхів сполучення організовував боротьбу з безпритульністю на залізниці; міжвідомча Комісія 3 поліпшення життя дітей при ВЦВК координувала зусилля всіх відомств.

Отже, система допомоги дітям та їх захисту, організована органами радянської влади, включала в себе практичні заходи, спрямовані на захист прав та інтересів підростаючого покоління, на створення нормальних умов для його розвитку та виховання. Реалізовувалася вона за рахунок державного та місцевого бюджетів, громадських організацій, спеціально створених фондів, благодійної діяльності. Мали місце і суттєві прорахунки у реалізації державної програми допомоги дітям, які полягали у спробах застосувати на практиці ідеологічні установки та недооцінювання реальної ситуації, яка на той час складалася, брак коштів на реалізацію важливих соціальних програм, перегини у бік занадто м'якого ставлення до неповнолітніх правопорушників і злочинців, що переходило у розряд вседозволеності. Однак основними соціальними проблемами у галузі охорони дитинства продовжували й надалі залишатися дитяча безпритульність і злочинність.

\footnotetext{
${ }^{18}$ Смирнова T.M. Дети страны Советов: От государственной политики к реалиям повседневной жизни. 19171949 гг. Москва: Институт российской истории РАН; Центр гуманитарных инициатив, 2015. С. 63.

${ }^{19}$ Дети ГУЛАГа. 1918-1956 / Сост. С.С. Виленский. Москва, 2002. С. 23.

${ }^{20}$ Собрание узаконений и распоряжений рабоче-крестьянского правительства РСФСР. Отдел второй. 1925. № 8. Ст. 57. URL: http://7law.info/ussr/act2i/u438.htm
} 


\title{
Formation of the Regulatory Framework and Organizational Bases of the State Aid to Children in the USSR in the 1920s
}

\begin{abstract}
The article investigates the beginning of the formation of the legal framework for state aid to children in the 1920s. There was a radical transformation of the old system of social protection of childhood and the emergence of its new directions. The Soviet authorities declared the protection of the rights of minors a priority of their activities. With the implementation of such a policy of the Soviet government, a number of social problems immediately intensified, among which the problem of mass child homelessness and neglect required a primary solution. The understanding of the concept of «homelessness» at that time and its application in the then legal acts was clarified.

Social protection of childhood was expressed in the formation of regulations, various state and public organizations for the protection of minors, in the creation of various children's institutions, in providing material and legal assistance to children and their families, in access to general and vocational education, employment of adolescents, their protection labor. The activities of several structures dealing with the social protection of children were organized the People's Commissariats of Education, Internal Affairs, Railways, and the interdepartmental Commission for the Improvement of Children's Lives at the Central Executive Committee coordinated the efforts of all departments.

System of assistance to children and their protection, organized by the Soviet authorities, included practical measures aimed at protecting the rights and interests of the younger generation, to create normal conditions for its development and education. It was implemented at the expense of state and local budgets, public organizations, specially created funds, charitable activities.
\end{abstract}

Keywords: Ukrainian SSR, RSFSR, decree, resolution, commissions, public organizations , help for children, homelessness 